Fourth International Conference on Sustainable Construction Materials and Technologies http://www.claisse.info/Proceedings.htm

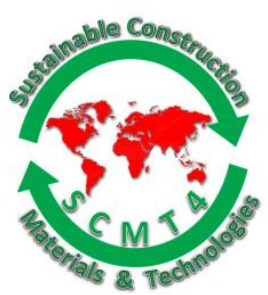

SCMT4

Las Vegas, USA, August 7-11, 2016

\title{
Fly Ash - An Important Ingredient for use in Hot-Mix ASHphalt Concrete
}

\author{
Bruce W. Ramme ${ }^{1 a}$, Art Covi ${ }^{1 b}$, Ahmed Faheem², and Konstantin Sobolev ${ }^{3}$ \\ ${ }^{1}$ We Energies, 333 W. Everett Street, Milwaukee, WI 53203, USA, ${ }^{1 a}$ Email: <bruce.ramme@we- \\ energies.com>, ${ }^{l b}$ Email: <art.covi@gmail.com> \\ ${ }^{2}$ Department of Civil \& Environmental Engineering, College of Engineering, Temple University, 1947 \\ North 12th St., Philadelphia, Pennsylvania 19122, USA, Email: 〈afaheem@temple.edu> \\ ${ }^{3}$ Department of Civil and Environmental Engineering, College of Engineering and Applied Science, \\ University of Wisconsin-Milwaukee, 3200 North Cramer Street, Milwaukee, WI 5321, USA, \\ Email: 〈sobolev@uwm.edu>
}

\begin{abstract}
This paper presents an overview of laboratory and field demonstration work with beneficial use of fly ash in hot-mix asphalt. The blend of asphalt binder and fly ash is named "ASHphalt". The field demonstration took place at We Energies, an electric, gas and steam utility headquartered in Milwaukee, Wisconsin, USA. Environmental sustainability benefits include conservation of energy and natural resources as well as reducing $\mathrm{CO}_{2}$ and other environmental impacts. Economic and social benefits include development of construction technologies for longer life pavements with reduced maintenance costs, and reduced impacts for pavement users.
\end{abstract}

The benefits of ASHphalt include: improved workability, easier compaction to specified density, improved binder aging resistance, a reduction in age-related cracking, extending the asphalt binder or reduction of binder content, a reduction in binder related issues, thermal stress relief, and reduced potential for thermal cracking. This paper shares the results of some laboratory testing and field demonstration work.

\section{INTRODUCTION}

The United States has more than 4.2 million km (2.6 million miles) of paved roads and highways, and $93 \%$ of those are surfaced with asphalt concrete. Many of those are full-depth asphalt pavements; others are asphalt overlays used to restore the performance of deteriorating concrete pavements. Each year, about 4,000 asphalt plants in the U.S. produce 450 to 500 million metric tons (500 to 550 million tons) of asphalt pavement material worth in excess of $\$ 30$ billion [National Asphalt Pavement Association, 2016]. With continual repair of aging U.S. transportation infrastructure and increasing transportation volumes, high-performance paving materials are needed that beneficially incorporate spherically shaped fly ash with sustainability benefits such as improved performance and extended service life for society. In 2014, 
2,800 metric tons ( 3,100 tons) of fly ash were utilized in asphalt mixtures in the U.S.A (States of Mississippi, Texas and Wisconsin).

Improving asphalt pavement performance can be achieved by means of additives to expand use over a wider range of temperatures and traffic loading. The modification of asphalt is commonly achieved through blending asphalt with manufactured products; such as polymers. The use of fly ash to enhance the performance of asphalt concrete has been demonstrated but had not yet been adopted on a commercial scale [Tapkin, 2008] [Sobolev et al., 2014]. The use of ASTM C 618 Class C fly ash has received most of the research focus. Class F fly ash and other Coal Combustion Products (CCPs) warrant additional exploration for potential use as an ingredient in asphalt mixtures, especially the synergy between polymer modification and fly ash particles. The blend of bitumen and finely divided spherical particles create a dense mix referred to as "mastic". Since the early 1900's [Richardson, 1905] it was noted that the use of mineral fillers in asphalt increases the stiffness of the asphalt-filler mix. Fly ash in asphalt bitumen can be considered an effective material in a viscoelastic matrix [Sobolev et al., 2014]. Fillers for asphalt pavement applications are defined by AASHTO M 17 (ASTM D242) as finely divided minerals, such as rock dust (e.g., granite and limestone), slag dust, hydrated lime, hydraulic cement, fly ash, loess, or other suitable mineral matter. The typical maximum particle size of fillers in asphalt is less than 75 microns. Although fillers, in general, usually represent less than $8 \%$ of Hot Mix Asphalt (HMA) by mass, the interactions of fillers with asphalt binder, and/or coarse and fine aggregates, affect the field performance. Furthermore, the use of fly ash in HMA has shown that it does not behave similar to typical fillers [Faheem, et al 2012] [Faheem et al 2010] [Bautista et al 2015]. In fact evidence point to fly ash acting as an enhancer of binder performance with respect to most common pavement distresses, and further extends the effect of the polymer modification [Bautista et al 2015] [Sobolev et al 2014]. These observations warrant further research on ASHphalt beyond the typical approach of considering fly ash as a mineral filler, but rather considering ASHphalt as an enhanced standalone product.

\section{BACKGROUND - FLY ASH UTILIZATION AND ASPHALT}

The latest survey of asphalt producers' use of recycled materials and warm-mix asphalt finds that almost a third of all asphalt produced during the 2014 construction season was produced using warm-mix asphalt technologies [National Asphalt Pavement Association, 2016]. The survey also found that about 71.9 million tons of reclaimed asphalt pavement (RAP) and 1.78 million metric tons (1.96 million tons) of reclaimed asphalt shingles (RAS) were used in new asphalt pavement mixes in the United States during 2014. In 2014, only 2,800 metric tons (3,100 tons) of fly ash was reportedly utilized in asphalt mixtures (in Mississippi, Texas and Wisconsin).

Combustion of coal in the United States generates approximately 118 million metric tons (130 million tons) of coal combustion products annually in the form of fly ash, bottom ash, slag, and flue gas desulfurization materials. Since the widespread installation of electrostatic precipitators in the early 1970's, utilization of coal combustion products in the United States has gradually grown to over 56 million metric tons (62 million tons) (48\%) in 2014 [American Coal Ash Association, "2014 Coal Combustion Product (CCP) Production and Use Survey, 2015]. Significant quantities remain to be utilized, and as coal combustion product landfilling issues increase, more utilization options become cost effective for many utilities.

In 1980, utilization of We Energies coal combustion products stood at five percent and has grown to 102\% in 2014 [Meidl, 2015]. Since 1980, a significant amount of research was conducted to identify and evaluate beneficial application for combustion products materials at We Energies. Work at We Energies is focused on maintaining full utilization, identification of high-added value niches for combustion products, and developing new applications for additional combustion products available as a result of the acquisition of Wisconsin Public Service Company's coal fueled power plants by the WEC Energy Group in 2015 . 
Researchers have investigated the use of by-products such as fly ash in the construction industry to improve the material properties [Ramme and Tharaniyil 2013] and [Sobolev and Naik 2005]. Fly ash has been used extensively in concrete production; however, there are limited applications in which fly ash has been used in asphalt pavements [Ali et al. 1996] [Churchill et al. 1999] [Asi et al. 2005] [Tapkin 2008] [Faheem and Bahia, 2010] [Sobolev et al. 2011] [Sobolev et al. 2014]. However, in all these studies fly ash has been viewed as a filler with the expectation of performance similar to mineral fillers. [Sobolev et al. 2013 and 2014] reported that the incorporation of fly ash into asphalt mixtures (ASHphalt) improves the performance of asphalt. This effect is attributed to the unique spherical shape, beneficial size distribution and chemical properties of fly ash. The use of fly ash in bitumen materials is attractive as it improves performance and reduces costs and environmental impacts [Tapkin 2008]. The advantages of fly ash in asphalt include improved mixing, placing and compaction, stability, resistance to water damage, rutting resistance, flexibility, and resistance to freeze-thaw damage [Carpenter 1952] [Warden et al. 1952] [Zimmer 1970] [Sankaran and Rao 1973] [Henning 1974] [Tons et al. 1983] [Suheibani 1986] [Cabrera and Zoorob 1994] [Tapkin 2008] and [Bautista et al 2015].

Self-cementing Class $\mathrm{C}$ fly ash has also been utilized for full depth in-place reclamation of asphalt pavements, and for the stabilization of difficult soils used as a sub-base and base material for pavements, parking lots, and building slabs on grade [Crovetti 1998] [Wen 2003 and 2004].

An in-situ mixed rigid pavement construction process has also been developed that utilizes up to $100 \%$ recycled or by-product materials, including self-cementing Class $\mathrm{C}$ fly ash, for Eco-Pad pavements with up to a $30 \mathrm{~cm}$ (12 in) thickness. Crushed recycled concrete is used as an alternative for coarse aggregate, and bottom ash as an alternative to sand. A 50/50 blend of Class C fly ash and ground granulated blast furnace slag can be used as the cementitious materials or a 50/50 blend of portland cement and Class $\mathrm{C}$ fly ash can be used. The aggregates are tailgated and spread in specified layers on the subgrade. A single pass with an asphalt reclaimer is used to pre-blend the aggregates and water is added to target optimum moisture conditions for compaction. A vane feeder is used to apply the cementitious powdered materials. An asphalt reclaimer is used for mixing the ingredients in place followed immediately by vibratory rollers. The process uses asphalt construction equipment and the resulting surface texture appearance is like finished asphalt. [Ramme, et. al., 2007]

With the continual repair of the aging U.S. transportation infrastructure and the increased transportation volumes on U.S. highways, there is a need for paving materials with improved performance and longer service lives. Such high-performance paving materials can help meet today's sustainability objectives by incorporating by-products (e.g., waste glass, fly ash). For example, improving asphalt performance can be realized through polymer modification; however, this method is expensive due to the cost of polymers. Other solutions to improve asphalt performance are based upon particle packing theory and optimization of aggregates, which is realized with the use of mineral fillers such as limestone dust. Asphalt concrete mix modification can be realized by replacing common filler material with another suitable material in a process known as filler replacement. There are several materials available in the market (e.g., hydrated lime and portland cement) that can be used in place of another filler. Fly ash has been used extensively in concrete production; however, there are limited applications in which fly ash has been used in asphalt pavements [Ali et al. 1996] [Churchill et al. 1999] [Asi et al. 2005] [Faheem and Bahia 2010] [Sobolev and Naik 2005].

Pavement engineers are interested in fly ash filler replacement because fly ash usage is important not only for improved performance, but also for economic, environmental and social benefits. Fly ash is an affordable, readily-available local material, and adding fly ash to asphalt mixtures does not require specialized equipment or changes for skilled constructors. Despite these benefits, the application of fly ash in asphalt technology has not yet become commonly accepted. 
There also is work in progress at the Electric Power Research Institute [Warren 2015] that includes the characterization of 15 coal combustion products, including Class F fly ash, Class C fly ash, and spray dryer absorber material. Testing includes rheological testing using a dynamic shear rheometer (DSR), at high and low concentrations to measure the stiffness $\left(\mathrm{G}^{*}\right)$ of mastics at high temperatures; evaluation of the aging effects; long-term field simulation on the performance of mastics with coal combustion product using multiple stress creep recovery; fatigue resistance at intermediate temperatures; and thermal resistance at low temperatures, and the investigation of mechanical and durability performance of ASHphalt concrete.

\section{LABORATORY WORK AND MIXTURE DEVELOPMENT}

Materials. Two types of bitumen (provided by Valero Marketing and Supply) PG-58-28 (Louisiana DOTD Product Source Code 41DO) and PG-70-22M (Louisiana DOTD Product Source Code 41DQ) were used and mixed with different fillers.

\section{Mixture Preparation and Testing}

Table1. Chemical composition of Class $\mathrm{C}$ and $\mathrm{F}$ fly ash

\begin{tabular}{|c|c|c|c|c|}
\hline \multirow{2}{*}{ Chemical composition, \% } & \multirow{2}{*}{ Class $\mathrm{F}$} & \multirow{2}{*}{ Class C } & \multicolumn{2}{|c|}{ ASTM C 618 limits } \\
\hline & & & Class $\mathrm{F}$ & Class C \\
\hline Silicon Oxide, $\mathrm{SiO}_{2}$ & 49.9 & 32.9 & -- & - \\
\hline Aluminum Oxide, $\mathrm{Al}_{2} \mathrm{O}_{3}$ & 24.0 & 19.4 & -- & - \\
\hline Iron Oxide, $\mathrm{Fe}_{2} \mathrm{O}_{3}$ & 14.4 & 5.4 & - & - \\
\hline Total, $\mathrm{SiO}_{2}+\mathrm{Al}_{2} \mathrm{O}_{3}+\mathrm{Fe}_{2} \mathrm{O}_{3}$ & 88.0 & 57.7 & $70 \mathrm{~min}$ & $50 \mathrm{~min}$ \\
\hline Sulfur Trioxide, $\mathrm{SO}_{3}$ & 0.88 & 3.8 & $5.0 \max$ & $5.0 \max$ \\
\hline Calcium Oxide, $\mathrm{CaO}$ & 3.23 & 28.9 & -- & -- \\
\hline Magnesium Oxide, MgO & 0.98 & 4.8 & - & - \\
\hline Potassium Oxide, $\mathrm{K}_{2} \mathrm{O}$ & 2.46 & 0.3 & -- & - \\
\hline Moisture Content & 0.11 & 0.8 & $3.0 \max$ & $3.0 \max$ \\
\hline Loss on Ignition & 3.50 & 0.6 & $6.0 \max$ & $6.0 \max$ \\
\hline
\end{tabular}

\begin{tabular}{|r|c|c|c|c|}
\hline Physical Tests & \multirow{2}{*}{ Class F } & \multirow{2}{*}{ Class C } & \multicolumn{2}{|c|}{ ASTM C 618 limits } \\
\cline { 4 - 5 } & & & Class F & Class C \\
\hline Fineness, \% Retained on \#325 Sieve & 25.7 & 15.9 & 34 max & 34 max \\
\hline $\begin{array}{r}\text { Pozzolanic Activity Index with Portland } \\
\text { Cement, 28 days, \% }\end{array}$ & 93 & 79 & 75 min & 75 min \\
\hline Water Requirement, \% of Control & 103 & 89 & 105 max & 105 max \\
\hline Soundness, Autoclave Expansion, \% & 0.08 & 0.11 & 0.8 max & 0.8 max \\
\hline Specific Gravity & 2.30 & 2.58 & -- & - \\
\hline
\end{tabular}

The fly ash and filler ingredients used were Class F fly ash (FA F), Class C fly ash (FA C) and Siliceous Aggregate Fines (Fine Silica, FS). All fillers were sieved through a No. 200 mesh screen. The chemical and physical characteristics of the two types of fly ash are shown in Table 1. X-ray diffraction (XRD) and SEM images of these materials are included in Sobolev, et. al., 2013. It was also observed in the 
microstructural investigation (SEM) of the asphalt binders with fly ash that a crack-arresting effect occurred that was induced by the fly ash particles being uniformly incorporated into the bitumen matrix.

Rheological Investigation and Performance. A small quantity of each compound was placed in a plastic container to facilitate sample preparation. Approximately $1 \mathrm{ml}(0.03 \mathrm{oz})$ of the bitumen mixture was poured in a silicon rubber mold to produce a cylindrical tablet of 2.0 to $2.5 \mathrm{~mm}$ (0.08 to $0.10 \mathrm{in})$ deep and $18.0 \mathrm{~mm}(3 / 4 \mathrm{in})$ in diameter. The sample was left at room temperature to solidify for at least $15 \mathrm{~min}$. The sample was removed from the mold when was strong enough to handle. Then, the sample was placed on a flat silicon rubber surface and kept covered to prevent oxidation.

The rutting factor, $\mathrm{G}^{*} / \sin (\delta)$, and the dynamic viscosity, $\eta$ ', were determined using DSR at $52,58,64,70$, and $124^{\circ} \mathrm{C}\left(126,136,147,158\right.$, and $\left.255^{\circ} \mathrm{F}\right)$. It was observed that within the entire temperature range between 52 and $70^{\circ} \mathrm{C}\left(126\right.$ and $\left.158^{\circ} \mathrm{F}\right), \mathrm{G}^{*} / \sin (\delta)$ increased with the incorporation of fillers. The addition of lower quantities of fly ash, such as 5,15 , and $30 \%$ at $124^{\circ} \mathrm{C}\left(255^{\circ} \mathrm{F}\right)$, increased the dynamic viscosity values by 18,22 and $55 \%$, respectively, vs. the reference. The addition of fly ash also increased the rutting factor by 14,26 , and $40 \%$, improving the rutting resistance potential. The grade of bitumen with fillers can reach a higher grade if its rutting factor matches the value of reference at higher temperature (i.e., $58+6=64^{\circ} \mathrm{C}$ ). Such grade increase was observed when $15 \%$ fly ash was used. Despite the higher viscosity, fly ash may facilitate the mixing and compaction due to the predominance of spherical particles. The complex shear modulus, $\mathrm{G}^{*} / \sin (\delta)$, and the dynamic viscosity, $\eta$ ', were determined at 64 , $70,76,82$, and $124^{\circ} \mathrm{C}\left(147,158,169,180\right.$ and $\left.255^{\circ} \mathrm{F}\right)$. It was observed that at temperatures between 64 and $82^{\circ} \mathrm{C}\left(147\right.$ and $\left.180^{\circ} \mathrm{F}\right)$, the $\mathrm{G}^{*} / \sin (\delta)$ increased with the incorporation of fillers vs. the reference bitumen. The main improvement was observed when the dosage of fly ash increased up to $60 \%$. On the other hand, at $124^{\circ} \mathrm{C}\left(255^{\circ} \mathrm{F}\right)$, the $\eta^{\prime}$ increased with the incorporation of fillers vs. the reference asphalt binder. Additional details of the rheological investigation and performance are included in Sobolev, et. al., 2013.

Figure 1 shows paving approximately $1.5 \mathrm{mi}(2.4 \mathrm{~km})$ of roadway at the Oak Creek Power Plant in Wisconsin with both ASHphalt for comparison to a control section of asphalt concrete. Fly ash is not just another asphaltic concrete filler; it is an important ingredient. The spherical particles, size and chemistry of fly ash bring unique benefits to asphalt concrete, similar to portland cement concrete.

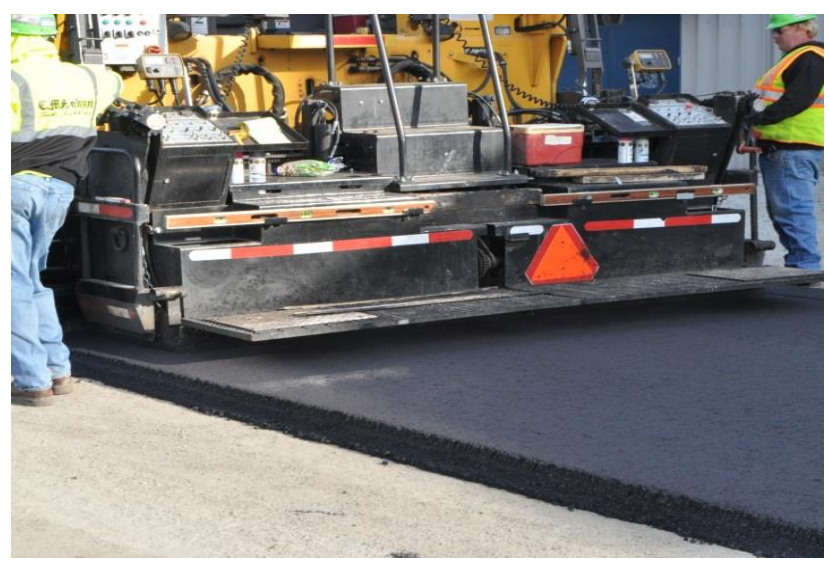

Figure 1. Paving at the Oak Creek Power Plant in Wisconsin with both ASHphalt for comparison to a control section of asphalt concrete

It is important to note that $\mathrm{G}^{*}$ is used to distinguish between different asphalt binders and their suitability for use in pavements in a given climate zone or under a given traffic load and speed based on the stiffness of the binder and mastic after aging. In order to evaluate the performance of the aged mastics at low 
temperatures, the Bending Beam Rheometer test was used to quantify the change in stiffness and measure the relaxing coefficient of a binder/mastic at low temperatures corresponding to the performance grade. [Bautista, et. al., 2015]

\section{FIELD DEMONSTRATION AND PERFORMANCE BENEFITS}

The laboratory results with specific We Energies fly ash sources were used to select an asphalt mixture for field implementation. During Fall 2012 an approximate $2.4 \mathrm{~km}$ (1.5 mile) section of internal road located at the Oak Creek Power Plant Site was paved with conventional asphalt as a control section and a section with a developed ASHphalt composition containing a 10 percent of Class $C$ fly ash replacement of the binder. Although the ASHphalt section was constructed with 10 percent less binder (replaced with fly ash) mixing, placement, and compaction efforts during construction did not show any difference compared to the control mix. Field target compaction density required for optimum service quality was achieved for both control and ASHphalt sections. This clearly indicates that while fly ash increased binder viscosity and stiffness, it did not hamper mix workability. In fact considering the asphalt content in ASHphalt section is 10 percent less than the control, this is a strong indication of the fly ash's ability to extend the volumetric effect of the binder through its unique spherical particle shape.

Nondestructive testing was performed on the completed test sections with a Falling Weight Deflectometer. After six-months, the average elastic modulus was measured to be $9 \%$ higher for the ASHphalt section compared to the control mixture without fly ash. The road continues to provide excellent service and performance after over 3 years of service.

\section{BENEFITS OF USING FLY ASH IN ASPHALT}

The potential benefits of using fly ash in asphalt that is reported in the literature, experienced in our laboratory studies, and/or demonstrated on our field demonstration are significant:

- Fly ash acts as an extender of asphalt bitumen volume.

- Fly ash improves the asphalt mixture workability and is easier to compact on site to targeted specified density.

- Fly ash improves the aging resistance of asphalt binder and delays aging related cracking. Crack arresting behavior of the spherical fly ash particles has been observed in SEM studies.

- Fly ash assists in relieving built up thermal stresses in asphalt mixtures thus reducing the potential for thermal cracking.

\section{SUMMARY AND CONCLUSIONS}

The use of fly ash as a filler material in asphalt concrete has been a topic for consideration but not a major emphasis in the industry. A new focus on bitumen binder amendment through the use of fly ash as an ingredient presents some attractive benefits beyond ordinary simple filler qualities. The term ASHphalt or asphalt concrete, which includes fly ash for improved performance holds great promise for growth and improved sustainability for pavements [Covi 2013].

A review of prior literature revealed that bitumen modified with fly ash provides a considerable economy of bitumen in asphalt designed for equivalent stability and enhanced fatigue life [Tapkin 2008]. Fly ash provided benefits to hot-mixed asphalt in terms of mixing, placing and compaction, stability, resistance to water damage, and flexibility [Warden et al., 1952] [Cabrera and Zoorob, 1994].

Investigation of indirect tensile strength, creep, and resilient modulus proved that the addition of Class $\mathrm{F}$ fly ash provided superior fatigue life, rut depth resistance, and tensile strength of asphalt concrete [Suheibani, 1986]. Application of fly ash as an anti-stripping agent in asphalt concrete demonstrated that 
the retained strengths of fly ash mixtures were considerably greater than those using natural filler material [Rosner et al. 1982]. Noticeable improvements were reported for asphalt hardening, moisture and freezethaw damage resistance, as well as improved rutting resistance, fatigue life, density, and tensile strength [Tons et al. 1983].

Microstructural investigation (SEM) of the asphalt binders with fly ash demonstrated crack-arresting behavior induced by the spherical fly ash particles incorporated into the bitumen matrix.

The investigation of the rheologcal performance of the asphalt binders was performed using DSR and confirmed the feasibility of fly ash application for improvement of the performance of asphalt binders. It was demonstrated that incorporating fly ash increases the rutting factor $\mathrm{G}^{*} / \sin (\delta)$ and dynamic viscosity $\eta$ ' of plain binders (PG-58-28 and PG-70-22). This behavior confirmed the observed interactions between the mineral filler and asphalt binder, as reported by [Faheem and Bahia 2010].

The application of fly ash increased the shear modulus of the bitumen, and the performance of modified material was superior to the plain bitumen. The best results were demonstrated by Class F fly ash supplied by We Energies, when the use of $15 \%$ Class F fly ash improved the grade of polymer-modified binder from PG-70 to PG-76, demonstrating a strong synergy of polymer modification and fly ash addition; the same grade shift was achieved by adding 30\% Class $\mathrm{C}$ fly ash. Both classes of fly ash when used at $60 \%$ increased the grade of bitumen from PG 58 to PG 64. These results can be used to predict the improved rutting resistance of Hot Mix Asphalt (HMA) mixtures manufactured with the addition of 5$60 \%$ fly ash.

Despite higher binder viscosity, fly ash may actually facilitate the mixing and compaction of ASHphalt due to the "micro-ball-bearing effect" governed by the predominance of spherical particles. This observation was reported by Cabrera and Zoorob [1994], who demonstrated that hot-mixed asphalt with fly ash can be mixed and compacted at reduced temperatures of $110^{\circ} \mathrm{C}$ and $85^{\circ} \mathrm{C}$. Such behavior can provide considerable energy savings without an additional asphalt cement requirement.

The findings of this demonstration set the foundation for further study on focused engineered benefits of ASHphalt depending on the pavement needs.

\section{REFERENCES} ash

Ali, N., Chan, J.S., Simms, S., Bushman, R., and Bergan, A.T. (1996). "Mechanistic evaluation of fly asphalt concrete mixtures." Journal of Materials in Civil Engineering, 8 (1): 19-25.Asphalt Pavement Industry Survey on Recycled Materials and Warm-Mix Asphalt Usage 2014, National Asphalt Pavement Association (NAPA). http://www.asphaltpavement.org

Asi, I., and Assa'ad, A. 2005. "Effect of Jordanian oil shale fly ash on asphalt mixes." Journal of Materials in Civil Engineering, 17 (5): 553-559.

American Coal Ash Association, "2014 Coal Combustion Product (CCP) Production and Use Survey

Results," https://www.acaa-usa.org

Bautista, E.G., Flickinger, J., Saha, R., Flores-Vivian, I., Faheem, A.F., and Sobolev, K. (2015);

"Effect of Coal Combustion Products on High Temperature Performance of Asphalt Mastics." Journal of Construction and Building Materials, Vol. 94, pp 572-578.

Cabrera, J.G., and Zoorob, S. (1994). "Design of low energy hot rolled asphalt." The Civil Engineering

Materials Unit, Department of Civil Engineering, University of Leeds, United Kingdom. 
Carpenter, C.A. (1952). “A comparative study of fillers in asphaltic concrete.” Public Roads, 27(5): $101-110$.

Churchill, E.V., and Amirkhanian, S.N.(1999). "Coal ash utilization in asphalt concrete mixtures." Journal of Materials in Civil Engineering, 11 (4): 295-301.

Covi, A., (2013) “ASHphalt Paving: Better Performance Using Fly Ash - Amended Binders in Asphaltic

Concrete.” Ash at Work, 2013 Issue 1, American Coal Ash Association, pp 22-25.

Crovetti, J.A., "Construction and Performance of a Fly Ash Stabilized CIR Asphalt Pavement in

Wisconsin," Transportation Research Record No. 1730, Transportation Research Board, National Research Council, Washington, D.C., pp 161-166.

Crovetti, J., (1998), Marquette University, Center for Highway and Traffic Engineering, "Design, Construction and Performance of Fly Ash Stabilized CIR Asphalt Pavements in Wisconsin." Prepared for Wisconsin Electric Power Company, October 1998.

Faheem, A.F., Bahia H.U. (2010). "Modelling of Asphalt Mastic in Terms of Filler-Bitumen Interaction."

EATA Conference, Parma, Italy, 11: 281-303.

Faheem, A. F., Hintz, C. Bahia, H.U. (2011) "Test Methods and Specification Criteria for Mineral Filler Used in HMA." NCHRP 9-45 Final Report.

Faheem, A.F. (2009). "Conceptual phenomenological model for interaction of asphalt binders with mineral fillers." Doctoral dissertation, University of Wisconsin Madison.

Faheem, A.F., Bahia H.U. (2010). "Modeling of asphalt mastic in terms of filler-bitumen interaction," Int J Road Mater Pavement, 11: 281-303

Faheem, A., Hintz, C., Bahia, H. (2012), "Influence of Filler Fractional Voids on Mastic and Mixture

Performance." Transportation Research Record: Journal of the Transportation Research Board, Volume 2294, 2012, pp 74-80.

Faheem, A., Bahia, H. (2010), "Modeling of Asphalt Mastic in Terms of Filler-Bitumen Interaction." The

International Journal of Road Materials and Pavements Design, Volume 11 - Special Issue, 2010, pp. 281-303.

Meidl, R.J.,(2015), “NR538 Reporting: Use of We Energies Coal Combustion Products - Year 2014.” Report submitted to the Wisconsin Department of Natural Resources, March 2015.

National Asphalt Pavement Association (2016), "Engineering Overview" (visited January 9, 2016). http://www.asphaltpavement.org

Ramme, B.W., Jansen, T., Ravil, A., and Anderson, D.B.(2007), "Eco-Pad In-Situ Mixed Concrete with a 93-100\% Total Recycled Content.," Proceedings of the Coventry University and the University of Wisconsin-Milwaukee Center for By-Products Utilization First International Conference on Sustainable Construction Materials and Technologies, held at Coventry University, UK, June 1113, 2007.

Ramme, B.W., and Tharaniyil, M.P. (2013), We Energies Combustion Products Utilization Handbook. Third Edition, 2013, available at https://www.we-energies.com/environmental/ccp_handbook.pdf

Richardson, C. (1905). The Modern Asphalt Pavement. J. Wiley \& Sons, NY. for

Rosner, J.C., Chehovits, J.G., and Morris, G.R. (1982). "Fly ash as a mineral filler and antistrip agent

asphalt concrete." Challenge of change- $6^{\text {th }}$ International Ash Utilization Symposium Proceedings. United States Department of Energy, Morgantown.

Sankaran, K.S., and Rao, D.R. (1973). "The influence of the quality of filler in asphaltic paving mixtures." Indian Roads Congress, 35: 141-151.

Sobolev, K., and Naik, T.R. (2005). "Performance as a Factor for Sustainability of the Cement Industry."

Proceedings of CANMET/ACI International Symposium on Sustainable Development of Cement and Concrete, Toronto, Canada, 295-312. 
Sobolev, K., Flores, I., Wasiuddin, N. M. (2011), "The Use of Fly Ash as Filler in Asphalt Cement: Phase

I," Final Report, UWM-We Energies, 2011, 17 pp.

Sobolev, K., Flores, I., Wasiuddin, N.M., Saha, R., Saltibus, N.E. (2014). "The Effect of Fly Ash on the

Rheological Properties of Bituminous Materials.” Fuel, 116(15): 471-477

Sobolev, K., Flores, I., Bohler, J. D., Faheem, A., Covi, A. (2013), “Application of Fly Ash in ASHphalt

Concrete:" from Challenges to Opportunities; Proceedings of World of Coal Ash Conference.

Suheibani, A.R.S. (1986). "The use of fly ash as an asphalt extender." PhD dissertation. University of Michigan, Ann Arbor.

Tapkin, S. (2008). "Improved asphalt aggregate mix properties by Portland cement modification."

Can. J. Civ. Eng. 35: 27-40. the

Tons, E. et al. (1983). "Fly ash as an asphalt reducer in bituminous base courses." Report prepared by

University of Michigan, The Board of Water and Light. Consumers Power Co. and Detroit Edison Co. Detroit, Michigan.

Warden, W.B., Hudson, S.B., and Howell H.C. (1952). "Evaluation of mineral filler in terms of practical

pavement performance." Proceedings of the Association of Asphalt Paving Technologists. 27(52): $101-110$

Warren, C., "Turning Expenses into Revenue.” EPRI Journal, Nov. 2015, http://eprijournal.com

Wen H., Tharaniyil M., Ramme B.W., and Krebs S. (2004), "Field Performance Evaluation of Class C Fly Ash in Full-depth Reclamation: Case History Study." Transportation Research Record, No 1869, Transportation Research Bd, Washington D.C., 2004, pp 41-46.

Wen H., Tharaniyil M., and Ramme B.W. (2003), "Investigation of Performance of Asphalt Pavement with Fly Ash Stabilized Cold In-Place Recycled Base Course.” Transportation Research Record, No 1819, Vol. 2, Transportation Research Bd., National Research Council, Washington D.C., 2003, pp. 27-31.

Zimmer, F.V. (1970). "Fly ash as bituminous filler." United States Department of Interior, Bureau of Mines. Washington, D.C., Engineering Overview (visited January 9, 2016). 